\title{
Collection of Leptocephali of the Japanese Eel in Waters South of the Okinawa Islands
}

\author{
Syoiti TANAKA* \\ (Received October 24, 1974)
}

\begin{abstract}
A total of 52 leptocephali of the Japanese eel, Anguilla japonica, was collected, with nets $4 \mathrm{~m}$ in diameter at the mouth opening, in an area south of an Okinawa Islands south of $24^{\circ} \mathrm{N}$ and west of $130^{\circ} \mathrm{E}$ from 27 th November to 5th December, 1973. Percentage of eels in total number of leptocephali at each station ranged from zero to $14.4 \%$, but most fell between 2 to $5 \%$ except in the cases of zero occurrence. The average number of eels per towing was as high as 1.9 individuals at the maximum. The density of the eels tended to be high on the $22^{\circ} \mathrm{N}$ line. The area where the eels were distributed seemed to correspond well with the high water temperature area of $25^{\circ} \mathrm{C}$ or higher at the $100 \mathrm{~m}$ depth layer. Most of the eels were obtained at mid-layer towings in the 10-70 $\mathrm{m}$ depth layers, and from this it appears that the eels are distributed rather sparsely at the surface layer. Though all of the eels were collected after dark a clear trend of collection depending on the time of night was not observed. A rather uniform distribution of the eels is suggested.
\end{abstract}

The spawning and early life history of the Japanese eel, Anguilla japonica, has long been studied by many scientists ${ }^{1-7}$, but the information so far obtained is quite fragmental and the entire picture is not clear. In 1972, The Ocean Research Institute of the University of Tokyo started a series of cruises of R. V. Hakuho-Maru for the study of the spawning ground and ecology of the eggs and the larvae of this species, with the cooperation of scientists interested in the subject from various parts of the nation. In its second cruise, KH-73-5, a total of 52 leptocephali of the Japanese eel in the developing stage and metamorphosing stage were collected ${ }^{8}$. This paper reports on these collections of leptocephali and also presents some information relevant to the ecology of the early life stages.

A total of 28 scientists whose names are listed in Table 1 went aboard the HakuhoMaru and all of them engaged in this study. This report is written by the director of the party on behalf of all the scientists aboard. The author should like to pay his hearty respects to the sincere effort of the scientists devoted to the purposes of this cruise. Scientific work during this cruise was conducted under full and timely cooperation of Captain I. TADAMA and all the crew of the R. V. Hakuho-Maru. Further, hearty support was given by Prof. M. NishIwAKI, director of the Ocean Research Institute, and its members concerned. On behalf of all the scientists aboard, the author wishes to express our profound thanks to these persons.

\footnotetext{
* Ocean Research Institute, University of Tokyo, Nakano, Tokyo (田中昌一：東京大学海洋研究所).
} 


\section{Outline of the cruise and the method of collection}

The cruise extended over 28 days from 21 st November when the vessel departed from Tokyo to 18 th December when she returned to the same port. The track chart is given in Fig. 1. The party consisted of 28 scientists whose names are listed in Table 1. S. TANAKA served as the director of the party. Five groups of five persons were

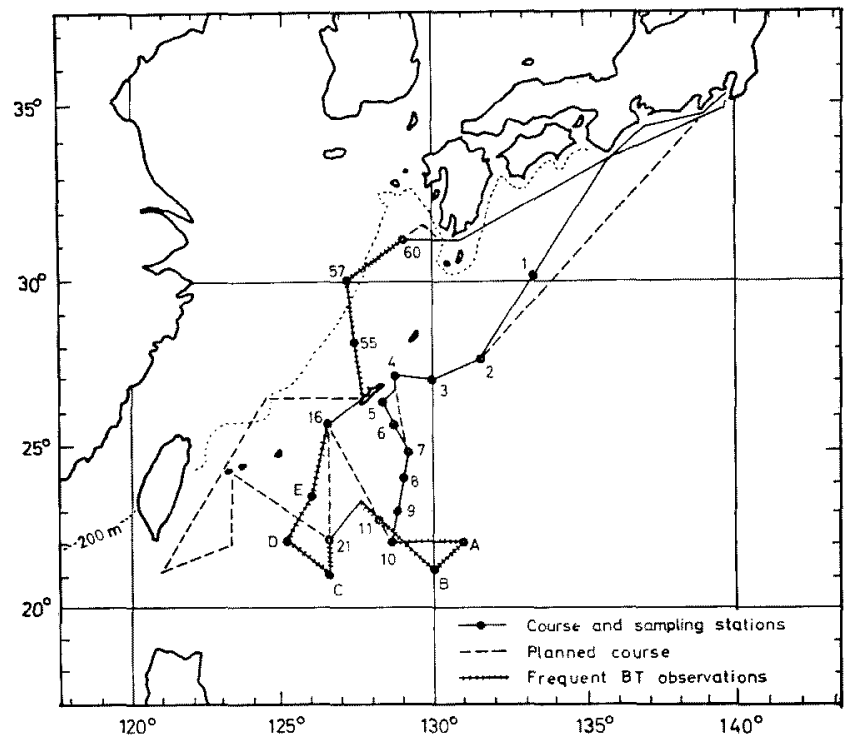

Fig. 1. Track chart of KH-73-5. Numerals and letters: Station numbers.

Table 1. Scientists aboard

Ocean Research Institute, University of Tokyo (Tokyo)

Syoiti TANaKA $^{\text {D }}$, Takeshi Kajihara ${ }^{* 1}$, Takeo Ishü ${ }^{* 1}$, Wataru SaKamoto*2, Hiroshi Hasumoto*2, Hirotaka OToBe, Tadashi Inagaki, Manabu Shrraishi, Yoshiharu MatsumiYA, Katsumi Tsukamoto, Chikakuni Haruta, Hitoshi Abe, Chien Hsiung Wang

Faculty of Agriculture, University of Tokyo (Tokyo)

Katsumi Matsushira, Yoshinori URA

College of Agriculture and Veterinary Medicine, Nihon University (Tokyo)

Nobuo SaKuraI

Faculty of Marine Science and Technology, Tokai University (Shimizu)

Tadashi Kubota*1, Takashi Abe, Shozo Sawamoto, Toru Nakao

Shimonoseki University of Fisheries (Shimonoseki)

Toru TAKAI*2, Osame TABETA*1

Faculty of Agriculture, Kyushu University (Fukuoka)

Seiichi Matsui, Teruo Honda, Singo FujII

Faculty of Fisheries, Nagasaki University (Nagasaki)

Akira KAKU

Faculty of Fisheries, Kagoshima University (Kagoshima)

Toshio SaISHo*1, Takakazu OzawA

D: Director, *1: Group leaders, *2: Other persons who were present at the executive committee. 
organized and these groups engaged in alternating shifts in net sampling operations, primary sorting of samples and STD and BT observations. The leader of each group is shown by $*$ in the table. The director, five leaders and scientists marked with $* *$ in the table formed the executive committee on board, and discussed and made decisions on the operation program and other important matters.

Large nets of $4 \mathrm{~m}$ in diameter of mouth opening of round and hexagon shapes, and ORI nets $(1.6 \mathrm{~m}$ in diameter) were mostly used. In the day time, these nets were lowered to deeper layers with the wire length of $500 \mathrm{~m}$ to $2000 \mathrm{~m}$, but no leptocephalus of the Japanese eel was collected. So, the day time towings were not taken into consideration in this paper, At night, towings were made horizontally for 30 minutes with the wire length of about $35 \mathrm{~m}$ (surface), $75 \mathrm{~m}$ or $150 \mathrm{~m}$, or stepwise with the wire length of $150 \mathrm{~m}, 75 \mathrm{~m}$ and surface for 10 minutes each. The material and mesh size was not the same between the round shaped and hexagon shaped nets but no distinction was made in the following analyses. Nets were towed at a speed of about 1.5 knot. Preliminary sortings into leptocephali, other fish larvae and others were made immediately after samples were taken aboard. Identification of the Japanese eels was conducted by $T$. TAKAI and $O$. TABETA ${ }^{8}$.

As for environment, water temperature observations were made with BT down to about $200 \mathrm{~m}$ depth at each sampling stations and others. STD observations and water samplings were also carried out at 11 stations.

In the evening of 27th November, the first leptocepalus of the Japanese eel for this cruise was collected at St. 10 and then the routine of the cruise was changed substantially from the planned one, and night towings were intensified. Frequent BT observations were made at a 12 mile interval (every one hour of cruise).

\section{Results}

The total numbers of leptocephali and leptocephali of the Japanese eel collected with $4 \mathrm{~m}$ nets and ORI nets by night towings are summarized in Table 2 . In this table towings other than the surface layer are lumped together in mid-layers towings. Leptocephali of Japanese eel were collected only by the $4 \mathrm{~m}$ nets. The number of them were not proportional to that of the total number of leptocephali. Percentage of the eels ranged from 0 to $14.4 \%$. Except in the cases of zero occurrence, most of percentages fell between 2 to $5 \%$. The average collection of the eels per one towing at each station was recorded 1.9 individuals at its maximum. The frequencies of the number of eels collected for each towing were 4 times of 4 specimens, 3 times of 3,6 times of 2 and 15 times of 1 , totaling to 52 .

As for the spatial distribution of the leptocephali, the average collection per one towing is shown for both the total leptocephali and the eels in Fig. 2. For the total 
leptocephali surface and mid-layers towings were combined whereas for the eels only mid-layers samples were used. The total leptocephali tended to be abundant in the waters adjacent to Kyushu and south of $22^{\circ} \mathrm{N}$. The density is relatively low near the

Table 2. Leptocephali collections by night towings

\begin{tabular}{|c|c|c|c|c|c|c|c|c|}
\hline \multirow{2}{*}{ Stn. } & \multirow{2}{*}{ Date } & \multirow{2}{*}{ Net } & \multirow{2}{*}{\multicolumn{2}{|c|}{ No, tow. }} & \multicolumn{2}{|c|}{ Leptocephali } & \multicolumn{2}{|c|}{ A. japonica } \\
\hline & & & & & No. & CPUE & No. & CPUE \\
\hline \multirow[t]{2}{*}{2} & Nov. 24 & $4 \mathrm{~m}$ & $\mathrm{~S}$ & 1 & 52 & 52 & & \\
\hline & & & $\mathbf{M}$ & 1 & 33 & 33 & & \\
\hline \multirow[t]{2}{*}{4} & Nov. $24-25$ & $4 \mathrm{~m}$ & $\mathrm{~S}$ & 3 & 17 & 5.7 & & \\
\hline & & & $\mathbf{M}$ & 2 & 13 & 6.5 & & \\
\hline \multirow[t]{2}{*}{6} & Nov. $25-26$ & ORI & $\mathrm{S}$ & 4 & 10 & 2.5 & & \\
\hline & & & $\mathbf{M}$ & 5 & 10 & 2.0 & & \\
\hline \multirow[t]{2}{*}{9} & Nov. 26 & $4 \mathrm{~m}$ & $\mathrm{~S}$ & 1 & 18 & 18 & & \\
\hline & & & $\mathbf{M}$ & 1 & 9 & 9 & & \\
\hline \multirow[t]{2}{*}{10} & Nov. 27-28 & $4 \mathrm{~m}$ & $\mathrm{~S}$ & 10 & 1203 & 120.3 & & \\
\hline & & & $\mathbf{M}$ & $\begin{array}{c}6 \\
(5)^{* 1}\end{array}$ & 560 & 93.3 & $\begin{array}{c}11 \\
(2.0 \%)^{* 2}\end{array}$ & 1.83 \\
\hline \multirow[t]{2}{*}{ A } & Nov. $28-29$ & ORI & $\mathbf{M}$ & 9 & 19 & 2.1 & & \\
\hline & & $4 \mathrm{~m}$ & $\mathbf{M}$ & 1 & 1 & 1.0 & & \\
\hline \multirow[t]{2}{*}{$\mathbf{B}$} & Nov. $29-30$ & $4 \mathrm{~m}$ & $S$ & 5 & 224 & 44.8 & & \\
\hline & & & $\mathbf{M}$ & $\begin{array}{c}9 \\
(1)\end{array}$ & 453 & 50.3 & $\begin{array}{c}2 \\
(0.4 \%)\end{array}$ & 0.22 \\
\hline \multirow[t]{2}{*}{11} & Nov. 30-Dec. 1 & $4 m$ & $S$ & $\begin{array}{c}5 \\
(1)\end{array}$ & 42 & 8.4 & $\begin{array}{c}1 \\
(2.4 \%)\end{array}$ & 0.2 \\
\hline & & & $\mathbf{M}$ & $\begin{array}{c}9 \\
(2)\end{array}$ & 92 & 10.2 & $\begin{array}{c}2 \\
(2.2 \%)\end{array}$ & 0.22 \\
\hline \multirow[t]{2}{*}{21} & Dec. $2-3$ & $4 \mathrm{~m}$ & $\mathbf{S}$ & 5 & 39 & 7.8 & & \\
\hline & & & M & $\begin{array}{c}9 \\
(7)\end{array}$ & 119 & 13.2 & $\begin{array}{c}17 \\
(14.3 \%)\end{array}$ & 1.89 \\
\hline \multirow[t]{2}{*}{$\mathrm{C}$} & Dec. 3-4 & $4 \mathrm{~m}$ & $\mathbf{S}$ & 2 & 4 & 2.0 & & \\
\hline & & & M & $\begin{array}{l}12 \\
(5)\end{array}$ & 128 & 10.7 & $\begin{array}{c}6 \\
(4.7 \%)\end{array}$ & 0.5 \\
\hline \multirow[t]{2}{*}{$\mathrm{D}$} & Dec. $4-5$ & $4 \mathrm{~m}$ & $\mathrm{~S}$ & $\begin{array}{c}3 \\
(2)\end{array}$ & 112 & 37.3 & $\begin{array}{c}5 \\
(4.5 \%)\end{array}$ & 1.67 \\
\hline & & & M & $\begin{array}{l}12 \\
(3)\end{array}$ & 184 & 15.3 & $\begin{array}{c}6 \\
(3.3 \%)\end{array}$ & 0.5 \\
\hline $\mathrm{E}$ & Dec. 5-6 & $4 m$ & $\mathbf{M}$ & $\begin{array}{c}6 \\
(2)\end{array}$ & 47 & 7.8 & $(4.3 \%)$ & 0.33 \\
\hline \multirow[t]{2}{*}{16} & Dec. 6 & $4 \mathrm{~m}$ & $\mathrm{~S}$ & 1 & 4 & 4.0 & & \\
\hline & & & $\mathbf{M}$ & 7 & 53 & 7.6 & & \\
\hline \multirow[t]{3}{*}{55} & Dec. $12-13$ & ORI & $\mathrm{S}$ & 2 & 4 & 2.0 & & \\
\hline & & & $\mathbf{M}$ & 6 & 10 & 1.7 & & \\
\hline & & $4 m$ & $\mathbf{M}$ & 4 & 18 & 4.5 & & \\
\hline \multirow[t]{2}{*}{57} & Dec. $13-14$ & $4 \mathrm{~m}$ & $\mathrm{~S}$ & 5 & 38 & 7.6 & & \\
\hline & & & $\mathbf{M}$ & 6 & 166 & 18.4 & & \\
\hline \multirow[t]{2}{*}{60} & Dec. $14-15$ & $4 \mathrm{~m}$ & $\mathrm{~S}$ & 4 & 186 & 46.5 & & \\
\hline & & & $\mathbf{M}$ & 9 & 374 & 41.6 & & \\
\hline
\end{tabular}

S: Surface M: Mid-layers

*1 The number of towings in which $A$. japonica were collected.

*2 Percentage of $A$. japonica among the total leptocephali. 
Okinawa Islands. Leptocephali of the eels occured only in the water south of $24^{\circ} \mathrm{N}$. The isopleth lines for the eels are drawn in the figure. In this study the differences between the round net and hexagonal net, and towing depths were neglected to calculate the average collection per one towing, and hence the values are given to describe only general trends.

The results from the observations of environmental factors would be reported in detail elsewhere by scientists concerned. The common feature of the vertical profile of the water temperature in the waters south of the Okinawa Islands is that the temperature is almost constant from the surface down to the depth of $50 \mathrm{~m}$ to

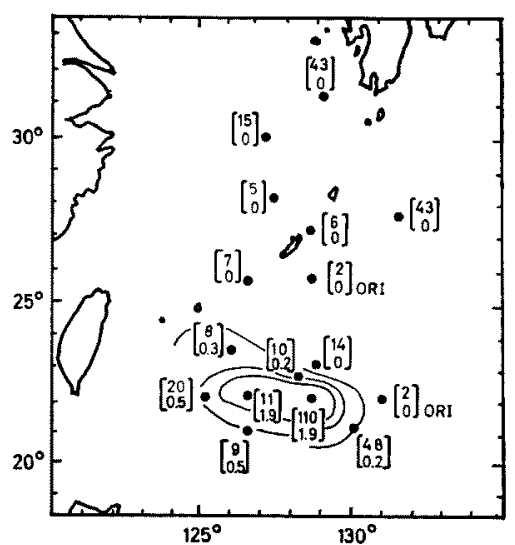

Fig. 2. The average number of collections per towings. Upper figures: Total leptocephali. Lower figures: Leptocephali of the Japanese eel, Contours: Equal density lines for the eels. $150 \mathrm{~m}$ and a relatively sharp thermocline is under this layer. As for the horizontal pattern, a high water temperature area of $25^{\circ} \mathrm{C}$ or higher at the $100 \mathrm{~m}$ depth layer prevailed south of $24^{\circ} \mathrm{N}$ and west of $129^{\circ} \mathrm{E}$. It seemed that the area where the eels were distributed corresponded well with this high water temperature area, and relationships between the ocean current system and the distribution of leptocephali of the eel were suggested.

As clearly seen in Table 2, most of the eels were obtained by the mid-layer towings. A comparison of collections from various depth layers are made in Table 3 for 7 stations where the eels were collected. The surface tow was such that the top of the mouth opening of net was in and out the water surface and the wire length was about $35 \mathrm{~m}$. The wire angle while towing ranged $55^{\circ}-75^{\circ}$ and then the wire length of $75 \mathrm{~m}$ is estimated to correspond to $10-25 \mathrm{~m}$ depth layer and $150 \mathrm{~m}$, to $30-70 \mathrm{~m}$ depth layer. The difference is quite obvious between the surface and mid-layers for the percentage occurrence of the eels among the total net towings and the number of eels collected per one towing. It may be said that leptocephali of the eel are distributed rather sparsely at the surface layer. The difference of collections between the wire length of

Table 3. Comparison of collections of the Japanese eel from various depths for 7 stations where eels occurred

\begin{tabular}{cccccc}
\hline Wire length & $\begin{array}{c}\text { Total no. } \\
\text { of towings }\end{array}$ & $\begin{array}{c}\text { No. of towings } \\
\text { with eels }\end{array}$ & Percentage & $\begin{array}{c}\text { No. of eels } \\
\text { collected }\end{array}$ & $\begin{array}{c}\text { No. per } \\
\text { towing }\end{array}$ \\
\hline Surface $(35 \mathrm{~m})$ & 30 & 3 & 10 & 6 & 0.20 \\
$75 \mathrm{~m}$ & 44 & 16 & 36 & 33 & 0.75 \\
$150 \mathrm{~m}$ & 9 & 5 & 56 & 7 & 0.78 \\
$150 \mathrm{~m}$ step & 10 & 4 & 40 & 6 & 0.60 \\
\hline
\end{tabular}


$75 \mathrm{~m}, 150 \mathrm{~m}$ and $150 \mathrm{~m}$ step towing is not clear. Two of 3 surface towings with eels occurred in a occasion of 2 successive surface towings. It happened that 4 eels were obtained in a surface towing and hence the surface layer was towed again at the next towing changing the original schedule, and one more eel was obtained.

In order to see the variation of collections depending on the time of a day, the number of leptocephali is shown against the time of net towing in Fig. 3. In this figure, individual eels are shown by small solid circles, but the number of total leptocephali is given in relative manner by the ratio of each collection to the average per one towing at the same station. Usually, the net towing operation was started after dark. In a few instances when the operation was started while it was still light, the number of the total leptocephali was very low. In a series of surface larval net towings at 2 hour intervals at St. 10, no leptocephalus was obtained in 8 towings from 08:00 in the morning to $18: 00$ in the evening. Some were collected in 5 of the 8 towings before

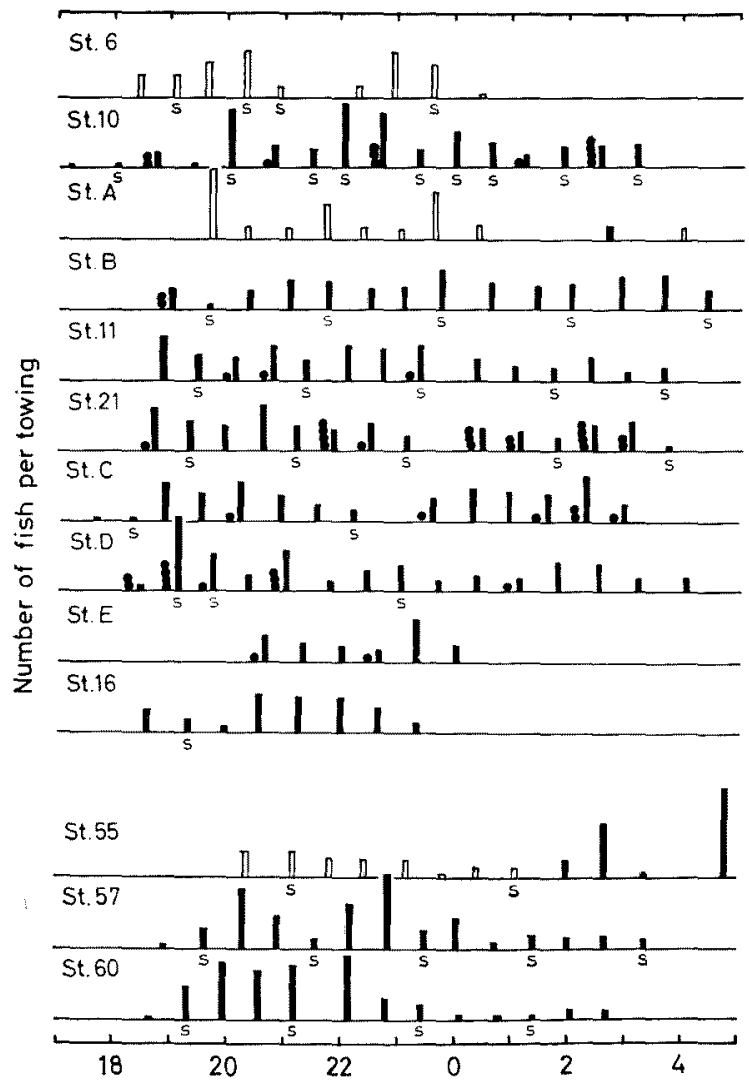

Fig. 3. Variation of the number of collections by the time of towings. Columns: Total leptocephali in relative value to the station's average, solid columns; $4 \mathrm{~m} \phi$ nets, open columns; ORI nets. Solid circles: Individual leptocephali of the eel. S: Surface towings. 
and at 06:00 and at and after 20:00. All of the eels were collected after dark. At St. 21, most of eels were obtained after 24:00 whereas at St. D, only one eel was obtained after 22:00. It might be due to that the wind velocity increased gradually on that night and the sea condition got quite rough after this time. Thus, no clear trend of collection depending on the time of night was observed. It may be worth noting that the catch of the total leptocephali sometimes showed wavy variations within a several hour period.

At St. 10, the eels were obtained from all of mid-layer towings except one before 18:00, and at St, 21, from all of mid-layer towings after 21:00. This suggests that leptocephali of the eel are distributed fairly uniformly in mid-layer over this sea area.

\section{Discussion}

In this cruise, a total of 52 leptocephali of the Japanese eel was collected from a considerably large area, and some information which could not be acquired from fragmental evidences in the past was obtained on the distribution and early life history of the Japanese eel. However the information is still insufficient to locate the spawning ground of this species. Before drawing the entire picture of the early life history, the following questions must be answered; where the eels are spawned, how are the larvae concentrated in the water south of the Okinawa Islands, and how are they transported to Japan. It is not known when the leptocephali of eel collected were sapwned. As the Japanese eels are distributed quite widely in the freshwater areas, from Japan and Korea to mainland China, Taiwan and further south, it is not likely that leptocephali from all of these areas are concentrated in this water south of the Okinawa Islands. It may be necessary to trace the spawning grounds for each of these local groups. In any event, collections of more specimens of various developmental stages are needed extending the searching area in both space and time from the point of the first mass collections of the leptocephali of the Japanese eel.

In this cruise, priority was put on collections of as many specimens as possible, and exact quantitative samplings were not tried. Most of quantitative studies on the distribution and ecology are still to be done under a carefully designed experimental program. A suggested relationship between the distribution of leptocephali of the eel and the warm water area endorses the importance of studies on environment such as oceanographical structure in this particular area in connection with the distribution, movement and migration of this species.

\section{References}

1) K. UCHIDA: Kagaku, 5, 138-140 (1935).

2) I. MatsuI: J. Shimonoseki Univ. Fish., 7, 151-167 (1957).

3) I. Matsui, T. Takal and A. Kataoka: ibid., 17, 17-23 (1968). 
4) I. Matsui and T. TakaI: ibid., 20, 13-18 (1971).

5) Y. Shojlma: This Bull., 32, 41-44 (1966).

6) Y. ShoJlma: Zool. Mag., 76, 167-171 (1967).

7) O. TABeta and T. TAKal: J. Shimonoseki Univ. Fish., 22, 49-53 (1973)

8) O. TABeta and T. TAkAI: This Bull., 41, 137-145 (1975). 